\title{
Fichte and Hegel: Critics of the Enlightenment
}

\section{J. Rivera de Rosales}

Universidad Nacional de Educación a Distancia (UNED, National University of Distance Education), 7, Senda del Rey, Madrid, 28224, Spain

For citation: Rivera de Rosales J. Fichte and Hegel: Critics of the Enlightenment. Vestnik of Saint Petersburg University. Philosophy and Conflict Studies, 2019, vol. 35, issue 2, pp. 308-319. https://doi.org/10.21638/spbu17.2019.207

This article discusses criticisms made by Fichte and Hegel of the Enlightment, and how similarities between these criticisms reveal an essential thought in German Idealism. Both, like Kant, considered that history is the development of the individual and especially of collective freedom. This takes place according to a dialectical process. Fichte placed the Enlightenment in the third period of history, a time when the individual became aware of his freedom but was detached from all external authority, an authority that had predominated during the preceding second period and struggled against it. Therefore, by considering only the individual as free, he did not address the community or even the divine root that makes it possible. Losing sight of this essence and becoming individually self-centred, he made a rational and cosmopolitan community and true freedom impossible. Hegel believed enlightened reason had also lost sight of the unitary and community essence of the Spirit and its actions. The reason for this is that human beings lived in an alienated social and political world dominated by the Lord of the world and not by reason. The enlightened individual subsequently went on to conquer social reality through cultural hegemony. However, he thought that he could build it only from himself, without considering the community essence of the Spirit, which he left to the field of religious faith and despised as superstition. This unilateral vision leads to the period of terror. In our globalized world, there is a greater need to achieve that community essence in our way of being human.

Keywords: Fichte, Hegel, Enlightenment, freedom, individual, community.

\section{Introduction: History as the sphere of realization of freedom}

Fichte divides the process of history into five periods corresponding to his method of fivefoldness (Fünffachheit), with the Enlightenment occupying the third place. For Fichte, history is not a mere accumulation of facta or facts, nor does it run in a straight line from a golden age downwards or from barbarism upwards - nor spirally according to the evolution of an organic body as in Herder, nor by "corsi e ricorsi", as Vico thought. Instead, history unfolds dialectically, with a necessary moment of negativity, dissolution of elements and opposition, so that various elements of the first unity emerge in their full power and effects. More precisely, the negativity of the Enlightenment, which Fichte described dramatically as the epoch of sinfulness, makes possible the necessary transition from an individual freedom limited by external authority of the second epoch of history, to a selfformed but rational freedom of the two last epochs, in which the human being sees and

(c) Санкт-Петербургский государственный университет, 2019 
experiences the common root of his freedom, a root that arises from the revelation or manifestation of God or the Absolute Being (das absolute Sein).

Indeed, according to Fichte, the theme of history is the establishment of the free legal and political conditions in a State and between all States. For Kant and Hegel as well, history is the realization of rational freedom in human relationships and the effective recognition, through laws and institutions, of the freedom of all human beings. In Kant, philosophy is supposed to discover the end, and the argument, of the interaction of rational individuals with each other in order to find meaning in it; the basis of this argument is that "the unsocial sociability" $[1, \mathrm{p} .20]$ will compel the human being to "achieve a generally civil law-governing society" [1, p. 22]. However, it remains unclear whether this purpose will be achieved because, as he explains in his Critique of Judgement, this idea has only a regulative, hermeneutical, and non-constitutive validity.

For Hegel, this realization of freedom is more certain, since it is guided by the Spirit of the world and the cunning of reason. When the subjective Spirit understands that happiness will not fully satisfy him, but that freedom is his essence, and also that this freedom can only be realized through the recognition of the freedom of all individuals, he turns to the sphere of the objective Spirit. There he makes it his mission to objectify and realize this recognition of all people as free beings through the laws, institutions and States. It is only within a State that contracts and morality, families and civil society are possible and secure. But who regulates the relationships between States? It is no longer the human being and his objective Spirit, but the World-Spirit itself through them, and even through their passions, a Spirit that is the first stage or manifestation of the Absolute Spirit. This universal Spirit is embodied in a nation and its State at all times, in the nation that would be more advanced in terms of the realization of freedom and reason at this time. This progression creates the sense and direction of history, and it is the task of the philosopher to recognize and clarify it.

Fichte gives the philosopher the same role, namely to show how the realization of freedom among people in a community takes place, and what stage it is at, or which stage it is experiencing. The human being, as a finite, rational creature, leads fundamentally a community existence, and "becomes a human only among men" [2, p.347]. He does this by recognizing each individual as a free being, by asking them to behave freely and actively, to treat others equally, and by the education of each individual by another, and for each other - and to that end, achieving all this through laws, institutions, and the establishment of a rational State. The ground for this freedom lies even deeper in the second Fichte, at the time when he wrote The Characteristics of the Present Age and Addresses to the German Nation: it is not just the freedom of human beings or the pure I, but the free life of the manifestation of the Absolute Being, on which that human freedom is founded, since this rational freedom is an appearance and realization of this life. The Absolute Being or God is by itself, of itself, and from itself (durch sich, von sich und aus sich), and for Fichte that means it is alive and not dead, it is not a thing or a product of anything else. Therefore, his appearance or manifestation, the absolute knowledge ( $a b$ solutes Wissen), should also be a free life in order to be a true revelation of the Absolute Being. Although it emerged from the Absolute as an image and not out of itself, it should show and develop its own free image-life from itself, of which the world and the human beings are moments. We live this life of Appearance, we are self-images of this forming life [3, p. 296-297]. 
But this is actually a task that guides the whole development of the manifestation or appearance of God (Erscheinung Gottes), and it is an obligation that appears in human beings and their history as legality, morality, religion, and science: the absolute Being should manifest itself as a reality and be recognized as such - something that can happen only in humanity. Therefore, every human being and every human society should act by itself, of itself, and from itself, that is, it should be free, since it is only then that they are truly suitable and accurate immanent appearances of the life which externalizes and reveals the Absolute Being. "Freedom should appear in the totality of consciousness of the [human] species, and enter into it as its own freedom, as true actual deed, and as the product of the species in its life, and forthcoming from its life" [3, p. 198]. Here we do not speak of arbitrary but of rational freedom. However, this end cannot be achieved in one fell swoop, either in individuals or even in a single society, because consciousness and knowledge the whole appearance of absolute Being is knowledge, absolute knowledge - need boundaries and distinctions, different elements and perspectives in order to recognize itself. The process of building community freedom is history.

Because reason is universal, "the first basic feature of the world-plan [in the history], the general dissemination of culture, is gradually promoted; and according to the same rule, it will go on incessantly until the whole [human] species, which inhabits our sphere, has melted into a single people-republic of culture" [3, p. 323]. Until then, everyone should act as a patriot in order to lead his nation to freedom and rational conditions, but always in relation to, and directed towards, the cosmopolitan purpose: "Cosmopolitanism is the ruling and dominant will that the end of the human race is attained in the human race. Patriotism is the will that this end is achieved first and foremost in the nation of which we are members, and that from which success spreads throughout the whole [human] race. ...that, in reality, cosmopolitanism would necessarily become patriotism. $<\ldots>$ And so every cosmopolitan becomes absolutely necessary, by virtue of his limitation by the nation, patriot" [4, p. 399-400]. It is in this sense that Fichte's Addresses to the German Nation has to be understood. History, too, moves within this cosmopolitan framework. It is necessarily a universal history of humanity, because "nothing individual can live in and of itself, but everything lives in the whole" [3, p.241].

\section{Fichte: The Enlightenment as the third epoch}

"The end of the earthly life of mankind is to establish in it all its relations with freedom according to reason; whereby this life falls into five main epochs" [3, p. 193]. This division into five epochs shows that an a priori idea, as a last criterion, orders, evaluates, and interprets historical events, and it is only thanks to this fact that this interpretation is philosophical: "The history of this gradual cultivation of the human race, as actual history, has in turn two intimately intertwined components: one a priori and other a posteriori" [3, p. 304]. As a result, the philosopher strives to understand the inner meaning and spiritual sense of world events. This a priori part of history is the plan of the world, just as it will be in Hegel, but there is also an a posteriori part in history: "Now this development of the human race does not occur in general, as the philosopher describes it in a single survey: but it gradually comes, disturbed by forces alien to it, at certain times, in certain places, under certain special circumstances. All these special environments do not in any way emerge from the a priori conception of that world-plan; they are that which is un-conceptualized 
in him, and, since it is the only concept for it, that which is not at all conceptualized; and here enters the pure empiric of history, its a posteriori, the actual history in its form" [3, p. 304] - insofar as history is "a part of science in general; namely, in addition to physics, the second part of empiricism" [3, p. 295]. Furthermore, these epochs, as in Hegel, are valid for nations that are at the forefront of the culture of their times, and even then, not to all the individuals within those nations

Here we limit ourselves to the a priori world-plan of history. The life of humans "goes forward according to a fixed plan, which must necessarily be reached, and therefore is sure reached. This plan is this: that the species develops itself in this life with freedom into the pure impression (Abdruck) of reason" [3, p. 206]. In the first two epochs, reason becomes active, and it is gradually discovered and raised to consciousness. These early effects of reason will run rather blindly, without insight into the grounds that is, through feeling or instinct. But they serve to ensure that rational freedom consciously reflects on itself and gradually it gains a clear idea of itself. In the last two stages, reason, free from instinct and already known, can organize the human world and human relationships through freedom and through people, who become aware of it, since reason and rational freedom can only work through the clear consciousness of humans. This explanation of man's vocation is made by the higher morality, a morality that is not merely formal like the Kantian one, by religion (above all by Johannine Christianity) and by philosophy, first by Kantian philosophy, and finally by Fichte's Science of Knowledge, which assumes that the real is a free life and not a dead thing. The third epoch is called Enlightenment, which is a transition between the two first and the two last periods of history.

In the first epoch of human history, the newly arisen reason is not recognized as such, and the human being was not reflexively aware of it. Therefore, it seemed like a dark instinct, a blind feeling, but in no way a freedom. Fichte describes this period as the "state of the innocence of the human race" [3, p.201]. Mythically, it would be the earthly paradise or the golden age, however Fichte speaks about the necessary assumption of an original normal people without science, art and history [3, p. 299-300]. In the second part of history, humanity begins to lose this innocence or the lack of a reflective consciousness of reason, and to become increasingly aware of its freedom. This happens especially in powerful people, more strongly possessed by this rational instinct, who rise above others as a compelling authority over their community. The universal validity of reason, which in the first epoch was an internal instinct, appears, therefore, in the second as external compulsion that gives the subordinates a feeling of their own freedom. Consequently, this awakening of the freedom of all causes the third stage of human history.

In this third epoch, the time of the Enlightenment, reason struggles against every external authority and force, that is, against every externality of freedom, because it understands that the free and rational human being should act out of himself, through himself and on his own initiative. In this sense, this view is closer to the true life of the phenomenon, which creates and develops its life as image (the world) by itself, of itself and from itself. Individuals liberated themselves from reason as the instinct of earlier stages and from any external authoritarian power that sought to determine what should be thought, done or felt. "Sapere aude! Have courage to use your own mind! Thus, that's the motto of the Enlightenment", Kant wrote [5, p. 35]. Individuals understand that any external authority that cannot be justified by one's own reason is irrational and tyranny. The principle of the third age is therefore liberation, the condition under which the species is only gradually 
freed from all external authority, but by no means completely free. The tool for this liberation is the concept - the opposite of blind instinct, faith, and obedience. The basic maxim of the age is thus: "nothing as being [reality] and as binding [duty] to be accepted, as that which one understands and clearly conceptualize" [3, p. 209]. This new freedom of each individual to speak and act facilitates science and the growing consciousness of reason, as it does the emergence of science itself. This third epoch of history is, for Fichte, already his own time, which lies between two worlds, between the world of darkness and external coercion, in which reason prevails at first directly through instinct and then indirectly as instinct through external authority on the one hand, and on the other, the world of clarity and freedom, where reason first through science, above all through the Science of Knowledge, and then through art, especially through Pestalozzi's pedagogy, enters into the knowledge of men and into life, forming and organizing the whole human community [3, p.206].

But what is the fundamental error of this historical period? What is the Fichte's main criticism against Enlightenment? The accusation is that in it the individual is held as the radical and true reality, as the last instance, which loses sight of the fact the essence and unity of all human beings, from which individual freedoms spring. The universality or common life of reason was abolished because it showed the face of arbitrary external authority, and the true root of freedom as the inner power of all, uniting all and giving the bond of life to all, was not yet discovered. Because the man of the Enlightenment was not yet aware of the universal life of reason and of the manifestation of absolute Being that the science of knowledge had discovered and explained, he put in the center of reality the life of the individual empirical subject as something that is independent from both, other people, and from the general life of the whole. That which is beyond his comprehension is nothing for him, only "that which he conceptualizes, which he understands himself immediately with the already existing and without effort or work inherited healthy human understanding" [3, p. 243]. Therefore, the Enlightenment only considers as truly real the life of the individual, its drive to self-preservation and well-being, and what is useful to him: "In relation to ethics, it is recognized as the only virtue, that one may promote one's own benefit... and for the only vice to miss his advantage... and that there is no other impulse in human being than that of self-interest" [3, p. 216]. Yet this is precisely the origin of evil and egoism, and that is why Fichte describes this epoch as one of sinfulness, because everything that truly exists is only a moment in the One Living Reason. It is "the epoch of liberation directly from the commanding external authority, indirectly from the dominion of reason-instinct and from reason in general in every form: the age of absolute indifference to all truth, and total untying (Ungebundenheit) without some guidance; the state of perfected sinfulness" [3, p. 207].

Although Fichte does not point this out, the thinking horizon of Enlightenment is similar to the first of five conceptions of reality or five worldviews, the five ways of being in the world and understand it: the sensible way. For Fichte the other four are higher: legality, higher morality, religion and philosophy. These views represent "the different possible stages and degrees of development of the inner spiritual life" [6, p. 105]. The lowest, the most superficial, worldview considers the sensible world to be the highest, the most truthful and existing for itself [6, p. 106]. This would not accurately reflect the attitude of the Enlightenment and it would show that there are not just five worldviews, but several more, as Hegel would demonstrate in his The Phenomenology of Spirit and a year later as 
The Characteristics of the Present Age. For the Enlightenment, freedom, not the thing, is first and the highest, but a freedom that the human identifies with his empirical individuality, and therefore he reifies it. It is equated with the interests of the empirical subject and therefore this attitude leads to similar goals and values as in the first worldview. For this reason, Fichte believes that empiricism prevails in the Enlightenment (as it does in the first worldview, because it is only through empirical experience that all that is useful for the empirical self-preservation and sensible well-being is recognized). But scepticism is also present around anything that wants to be beyond the body-world, like the objects of religion; "so also this [the religion] will turn to him into a mere happiness-doctrine" [3, p.216]. The whole life is therefore reduced to the sensible personal existence and reality as it is the case in the first worldview.

Fichte expressed such concern and criticism in Addresses to the German Nation. Since everyone during his time had only their own empirical interests in mind, in the manner of the German princes who made a deal with Napoleon, no one would do anything for the true freedom of Germany against the French occupation and oppression. Remaining in the third period of history only favored the invaders. The only solution and salvation for Germany that Fichte saw in this situation was the German people leaving this lowest worldview, overcoming the Enlightenment, and moving on to the fourth epoch of history. If that did not happen, the country would surrender to the French in anguish and fear of its empirical existence. It would do nothing for the advancement of freedom and free life, and it would transform itself into a people of the past and would no longer count for history because its spiritual reality and power would be destroyed. Thanks to Kantian philosophy and the Science of Knowledge, Germans could and should go, with total awareness, from the isolated empirical "I" of Enlightenment to the transcendental higher "We" of Idealism, which is rooted and grows in the communal divine and the free life of reason, and of the appearance of God, in order to live there freely and to act creatively, through a new culture that can and should bring the light and liberation to all mankind. But "Germans" were basically all those who understood and wanted to realize the good news of the Science of Knowledge, no matter where they were born or what language they spoke [7, p. 193-194].

\section{The Hegel's conception}

A year after The Characteristics of the Present Age (1806), Hegel presented a similar conception of the Enlightenment in his Phenomenology of the Spirit (1807). This should be regarded as significant for the attitude of German idealism. The decisive factor here is not that this criticism of the Enlightenment is not quite justified, because the Enlightenment also strongly emphasized the general validity of reason in the formation of the community, for example, by the idea of the universal human rights or in the social contract, but also in the Rousseau's difference between volonté de tous (will of all side by side) and volonté générale (general will as the essential and rational unity of all), or even in the intensive cultivation of the objective sciences. What is highlighted here is a certain closeness between Fichte, especially the second Fichte, in his appearance of the Absolute and its life, and Hegel in his realization of the idea through the spirit, because both thought and demanded a more substantial unity of free human beings than what the Enlightenment recognized. This should be considered in the face of a critique of modernity that is very common today, claiming that the subject of modern philosophy is an isolated being. 
Nothing is further from the truth. For instance, Kant affirms the following: "Every genus of rational beings is determined objectively, in the idea of reason, for a common purpose, namely the promotion of the highest as a common good" [8, p.97].

In the sixth chapter of the Phenomenology of the Spirit, called "The alienated Spirit. The culture" (or formation or education), Hegel interprets the historical development of the spirit from classical Greece to the German philosophy of his time. In paragraph B. II of this chapter, Hegel sets out his interpretation of the Enlightenment. The elements that come into play in dialectical tension are the universal essence or the ethical substance or be-in-itself (Ansichsein) of all spirits, and the self or self-consciousness of every individual. The first element, the ethical or political world, was dominated at first by the medieval feudal lord and later by the modern absolute monarch. Accordingly, this ethical world, which in truth is the work of self-consciousness and reason and forms the essence of individuals, appears to the rational individual as something foreign that does not belong to him and that he cannot rationally configure; therefore, reason is in contradiction to itself. This ethical world, consisting of the power of the state and of wealth or family property, although it is the essence of the individual, is not determined by him (by most individuals), and this is why it appears to be estranged from it, as a blind fate. The originality, the rights and the freedom of the self-consciousness of individuals are not recognized because they cannot shape the ethical world. Rather, this world is left to the arbitrariness of an absolute ruler and it is not recognized in its rational nature. Accordingly, the alienated individual spirit cannot regard the ethical world as his essence. All that leads to the revolution.

Here it could be said that Hegel focuses on the French Enlightenment, which led to a political revolution and to the guillotining of the Lord of the world, while in Germany instead the Enlightenment led to an internal revolution in the way of thinking, in Kantian critical philosophy. "In Germany the Enlightenment was on the side of theology; in France he immediately took a direction against the Church" [9, p. 526]. Hegel thought this was so because, in Germany, the Lutheran Reformation had triumphed [9, p. $492 \mathrm{ff}$.] and that had introduced three important elements towards an internal revolution. The first was against the Catholic externality, which had turned the remission of sins and union with God into a mere matter of external rites and of the sale of indulgences, therefore, the inner character of the German people (Innigkeit des deutschen Volkes) reacted. Second, the Reformation rejected the external authority of the Catholic Church and its Pope and strengthened the freedom of the individual and his direct relationship to God, and to his revelation without intermediaries. "That is the essential content of the Reformation: man is determined by himself to be free" [9, p. 497]. Third, the Reformation reconciled religion with the order of the mundane: it sanctified marriage against the chastity of monks, it abolished fasting and abstinence, it blessed money, work, industry, and commerce against poverty and mendicant orders: "through the Protestant church took place the reconciliation (Versöhnung) of religion with right. There is no religious and holy conscience separate and opposed to worldly right" [9, p.539]. In addition, the Reformation did not separate itself from science, philosophy, and humanist literature.

From the previous chapter, chapter V, B: "The realization of rational self-consciousness by itself", the process of formation of the spirit enters "the realm of ethics" (das Reich der Sittlichkeit), the sphere of acting or practice reason, which actively configures its objectivity in the world because it knows that without it, it lacks truth, it lacks reality. That is "the beginning of its ethical experience of the world" [10, p. 268], first throughout that 
chapter V, as individuals, and then in chapter VI as historical communities succeeding one another, "for ethicity is nothing other than the absolute spiritual unity of the essence of individuals in the autonomous reality of those individuals" [10, p. 264], the unity of individual and community. Individuals should remain autonomous among themselves, conscious of their free individuality (that is their certainty), and yet essential or substantially united in a real community, where their truth is realized: "Reason is Spirit when the certainty of being all reality rises to the truth" [10, p.324]. Individuals are essentially united in the objectified spirit, "in the life of a people" [10, p. 264], in their customs, in their laws, in their institutions, in their culture, in their work, which make them interdependent. That historically objectified reason is the ground and substance of individuals; in it they carry out their actions and their ends, they become rational beings. "The Spirit is the ethical life of a people" [10, p. 326], the ethos of a historical community. Fichte had said: "The human being only among human beings becomes a human being" [2, p. 347]. Therefore, the human being is essentially a social and community being, because it is only through a human relationship, through language and concepts, that is, through education, that he reaches his rationality.

Hegel opened this chapter VI, which was dedicated to the Spirit, with Greece, where the immediate unity of individuals and polis would have occurred, with predominance of the community over the individuals. Then, in a second stage, the dissolution of that unit begins, already with the Roman Empire, and individuals leave the "maternal womb" of the Spirit of the people, affirming their free and rational individuality. This dissolution of the first unity is for Hegel a necessary process, the second stage of a dialectical process, since the elements included in that primary and naive unity have to come to light, to be deployed, to be known and recognized as such in all its potentiality and limits: there is profit, real conflict is necessary, because consciousness requires distinction, opposition. Therefore, in the third stage, the Spirit is forced to return to itself, first to its moral conscience, which would happen in the philosophy of Kant, and finally to a reconciliation and mutual forgiveness, a threshold towards religion, the utopia that Hegel proposes in his Phenomenology of the Spirit - a utopia, because it did not occur in reality.

Since free individuality was not recognized in the Middle Ages or in early Modernity and at that time the individual had certainty to be free, albeit not truth and reality, the affirmation of the free individual that takes place during the Enlightenment was achieved by separating it from the essential unity of individuals in the community, staying away from its truth; that is the central idea. The being-for-itself (Fürsichsein) or consciousness has come out of the life of the ethical substance, of its being-in-itself (Ansichsein), of its truth, so that the Spirit appears as the autonomous reality of individual consciousness as certainty. The Spirit has the certainty of being the maker of the community, the one who builds it, but in fact as an individual it does not determine the reality of his community, and therefore that reality is alien to him, because it is dominated by the Lord of the world and his caprice, not by reason. The dialectic of the master and the servant is reproduced here at a historical level. But the recapture of reality or truth on the part of that Spirit, who is estranged from himself, will not be achieved through physical work, the stoic or sceptical denial of the reality of the world or by the withdrawal towards a unhappy religious consciousness, which was the reaction of the servant, but through the Bildung, through the intellectual formation or education, through culture, the own thing of the Spirit, the knowledge on himself, which is a process of elevation of the individual to the universal 
and to essential thing (that is the education). It will be a culture capable of criticizing the irrationality of the status quo, the arbitrariness of the Lord of the world and of the state of society, capable of conquering, as Gramsci would say, the cultural hegemony that leads to a social and political revolution, to the real reconquest of the world, and also to possessing its truth and realization. We are now at the level of reason, and the rational spirit knows that it has to conquer the world to have truth, Wirklichkeit, reality.

In the alienated world of the Spirit, which is the second stage, the stage of dispersion of the elements, there are two dialectical processes between the Lord and the servants. The first is the double attitude that the servants can take before the lord of the world: that of the noble conscience and that of the vile conscience. It may happen that (1) the selfconsciousness or individual accepts his ethical and historical world and identifies with it, with both, the power of the feudal Lord or absolute Monarch and the so distributed wealth, and the individual qualifies them as good and universally valid. Thus arises the noble conscience, the vassal faithful to the Lord of the world. Or that (2) the individual realizes the contradiction, considers the political situation as bad, that the absolute power of the Monarch nullifies its being-for-itself, and that wealth insulates individuals, and then he becomes a vile and treacherous conscience. The dialectic of Hegel is aimed at showing the relativity and inversion of both perspectives, their essential respectivity, since they are two sides of the same coin: the non-recognition of the rational individual in the configuration of the ethical and political world and that this world is governed not by reason and rational freedom, but by the arbitrariness of the Lord of the world. Insofar as the noble conscience does not renounce its being for itself, it will always be able to rise up: the nobles against the Monarch. The vile conscience, on the other hand, when recognizing the contradiction is more true and sincere, preserves its freedom of criticism, and is the one that will carry forward the dialectical process, which will lead to the following dialectical opposition: that of the Enlightenment.

The real alienation of the servants in front of the Lord of the world leads to another alienation in the ideal sphere of the understanding of reality. The real dialectic is followed here by a dialectic between faith and the illustrated reason, or pure insight, or Enlightenment, two interpretations of reality that confront each other over which one should be estimated as true, valid and binding. One is the religious faith that seeks to grasp the substance and the universal nature of human beings. But this faith does not think about the ethical substance using the (dialectical and speculative) concept - that is, not with the appropriate means, and therefore places it in God as a substance separate from self-consciousness. Thus, self-consciousness remains estranged from its content as it is estranged from its ethical real world.

The other worldview arises from self-consciousness itself. The ethical world belongs to the Lord; therefore, the enlightened self-consciousness has withdrawn within itself and, from there, it tries to gain a clear insight into the world purely from itself. In this process, its formation (Bildung), its culture and the cultivation of itself, such as the behaviour of the servant in front of the Lord, are carried out, but this time not through physical but through spiritual work. This mode of understanding invokes the concept, the reason, the pure intellection (die reine Einsicht) of self-consciousness: one must think for oneself, "sapere aude" (Kant). In this way, the spirit, as a rational self-consciousness, recovers its autonomy, its originality in the face of all the tutelage of the Lord of the world and of all authority, as well as that of the given faith. From there, from that thinking, he performs 
his own formation (Bildung) or education, ascends to the universal of reason, criticizes the state of the world and presents a program of liberation. That is the guiding principle of the modern age, which Hegel believes to be superior to Greek unity, specifically, the principle of the autonomy of individuality, subjective freedom and its right to self-determination, where everyone is recognized as free; the supreme right of the subject is not to be forced to consider as good and just that which contradicts his rational moral convictions. That freedom of the individual is born, according to Hegel, with Christianity: the freedom of the children of God, strengthened against the Church in the Reformation and established as a norm before all authority in the Enlightenment and Kantian philosophy. That is the great achievement of Kant's moral philosophy, "to emphasize the pure and unconditioned self-determination of the will as the root of duty" [11, p.252].

It can be concluded that, through cultural hegemony, the enlightener wants to conquer the world, or at least the ethical and political world. Yet in this activity of thought, self-consciousness does not start from the essence or content of the objective spirit, from his being-in-itself (An-sich-sein), because that has remained on the side of faith. Instead, it starts from his mere certainty lacking in historical truth - that is, he starts from the mere being-for-itself (Fürsichsein) or self-consciousness of individuals, so that the criterion is to accept nothing but what every rational being can achieve and understands on its own. The pure insight of self-consciousness "conceives nothing but the self and everything as the self, that is, he conceptualizes everything, erases all objectivity, and transforms all beingin-itself into being-for-itself" [10, p. 361]. He behaves as if the ethical world had started with him. In that lies its one-sidedness. The Enlightenment has recognized the rights of self-consciousness, of the rational individual, but it has detached it from its essence, from its ethical substance, it does not conceive it as arising from it and the free and rational individuals appear in an isolated way; Fichte and Hegel coincide in this essential point of criticism to the Enlightenment. "The Enlightenment has eliminated and erased everything that is speculative about human and divine things" [9, p.524] and this content or essence has been handed over to the faith $[9,526]$. It is therefore an abstract and finite reason, which is only addressed by the formal principles of identity and by not contradiction.

For Hegel, the two forms of this spirit, faith and pure insight, are both sides of an alienated world that appear separate because of their one-sidedness - certainty and truth (essence, content) - which is why both interpretations or perspectives are unilateral and do not properly comprehend the real. Faith assumes that all ethical content is given, and the enlightener claims that the content is created by the self-consciousness of individuals. The rights of being-for-itself and self-consciousness, that is, the rights that the free and rational man, has to understand all content of morality from reason are not grasped by faith. The Enlightenment, on the other hand, erroneously believes that its conscious individuality is elevated above all objective moral content and over every other instance. Self-consciousness puts itself in the center of reality and therefore considers everything else useful for itself and its individual freedom. For this reason, both philosophers, Fichte and Hegel, assume that the Enlightenment reduces the essence to the individually useful.

According to Hegel, this view of enlightened consciousness, which separates itself from its essential content in its freedom and thus remains empty, leads to the French Revolution, in which the self-consciousness of individuals wants to create the entire ethical world from themselves and from zero, as if reason had hitherto been without power, and man should not really have to depend and rely on what was produced and formed by 
reason in society. What is actually achieved with this arbitrariness, however, is the triggering of a period of terror in which all those who are deemed to be opponents or useless were killed. For Hegel this is "the fury of destroying" [11, p. 50].

The solution lies in the synthesis of both views, in the inner free and rational insight of the individual through the (philosophical) education and the conviction that the universal substance or objective spirit according to Hegel, or the absolute appearance of the absolute Being according to Fichte, or the free and just intersubjectivity in actual terms, represents its most intimate essence, takes charge of it and work for it. Only there is one's own freedom recognized and confirmed, the modern principle behind which we should not fall [12, p. 367]. We live in a globalized world, are ever more closely connected, and the need for a substantial communal and cosmopolitan bond to connect us all becomes all the stronger in order to become human, to live in peace and justice, and to be truly liberated. This bond should be sought and found in the essence of freedom, since it is not merely an individual matter, but it is rather an essentially interpersonal thing, and it should also be founded, empirically and materially, in the necessary participation of all to keep us alive in a habitable planet.

\section{References}

1. Kant, I. (1968), "Idee zu einer allgemeinen Geschichte in weltbürgerlicher Absicht", in Kants Werke, vol. 8, Walter de Gruyter, Berlin, Germany.

2. Fichte, J.G. (1966), "Grundlage des Naturrechts nach Prinzipien der Wissenschaftslehre", in Fichte, J. G., Gesamtausgabe, vol. I/3, Frommann Verlag, Stuttgart, Germany.

3. Fichte, J.G. (1991), "Die Grundzüge des gegenwärtigen Zeitalters", in Fichte, J.G., Gesamtausgabe, vol. I/8, Frommann Verlag, Stuttgart, Germany.

4. Fichte, J. G. (1993), "Der Patriotismus und sein Gegenteil”, in Fichte, J. G., Gesamtausgabe, vol. II/9, Frommann Verlag, Stuttgart, Germany.

5. Kant, I. (1968), “Beantwortung der Frage: Was ist Aufklärung?”, in Kants Werke, vol. 8, Walter de Gruyter, Berlin, Germany.

6. Fichte, J. G. (1995), "Anweisung zum seeligen Leben", in Fichte, J. G., Gesamtausgabe, vol. I/9, Frommann Verlag, Stuttgart, Germany.

7. Fichte, J. G. (2005), "Reden an die deutsche Nation", in Fichte, J. G., Gesamtausgabe, vol. I/10, Frommann Verlag, Stuttgart, Germany.

8. Kant, I. (1968), "Die Religion innerhalb der Grenze der bloßen Vernunft", in Kants Werke, vol. 6, Walter de Gruyter, Berlin, Germany.

9. Hegel, G. W. F. (1970), "Vorlesungen über die Philosophie der Geschichte", in Hegel, G. W. F., Werke in zwanzig Bände, vol. 12, Suhrkamp Verlag, Frankfurt, Germany.

10. Hegel, G. W.F. (1970), "Phänomenologie des Geistes", in Hegel, G. W.F., Werke in zwanzig Bände, vol. 3, Suhrkamp Verlag, Frankfurt, Germany.

11. Hegel, G. W. F. (1970), "Grundlinien der Philosophie des Rechts”, in Hegel, G. W. F., Werke in zwanzig Bände, vol. 7, Suhrkamp Verlag, Frankfurt, Germany.

12. Hegel, G.W.F. (1970), "Vorlesungen über die Geschichte der Philosophie III", in Hegel, G.W.F., Werke in zwanzig Bände, vol. 20, Suhrkamp Verlag, Frankfurt, Germany.

Author's information:

Jacinto Rivera de Rosales - Dr. Sci. in Philosophy, Professor; jrivera@fsof.uned.es 


\title{
Фихте и Гегель: критики Просвещения
}

\author{
Х. Ривера де Росалес \\ Национальный университет дистанционного обучения, \\ Испания, 28224, Мадрид, ул. Сенда дель Рей, 7
}

Для цитирования: Rivera de Rosales J. Fichte and Hegel: Critics of the Enlightenment // Вестник Санкт-Петербургского университета. Философия и конфликтология. 2019. Т. 35. Вып. 2. C. 308-319. https://doi.org/10.21638/spbu17.2019.207 (In English)

В статье рассматривается критика Просвещения Фихте и Гегелем, а также близость их критических подходов, в чем проявляется существенное содержание немецкого идеализма. Оба они, как и Кант, считали, что история - это развитие личности и, прежде всего, коллективной свободы. Это развитие происходит в соответствии с диалектическим процессом. Фихте поместил Просвещение в третий период истории, когда человек осознает свою свободу, но остается оторванным от всякой внешней власти, которая доминировала в течение предыдущего периода истории и боролась против личной свободы. Поэтому, рассматривая свободу лишь на уровне индивида, человек упускает ее общественное основание или даже ее божественный корень, теряет из виду ее сущность и становится эгоцентричным, делая таким образом рациональное и космополитическое сообщество и истинную свободу невозможными. Гегель считал, что просвещенный разум также потерял из виду унитарную и общинную сущность Духа и его действия. Причина этого заключается в том, что люди жили в отчужденном социальном и политическом мире, где царствовал Господь мира, а не разум. Впоследствии просвещенный человек завоевал социальную реальность посредством культурной гегемонии. Однако он полагал, что может построить ее лишь из себя как индивида, упуская при этом общинную сущность Духа, оставленную им религиозной вере, презираемой как суеверие. Это одностороннее видение приводит к террору. В нашем глобализованном мире достижение этой сущности сообщества необходимо, чтобы продолжать оставаться людьми.

Ключевые слова: Фихте, Гегель, Просвещение, индивид, сообщество.

Статья поступила в редакцию 30 августа 2018 г.; рекомендована в печать 7 февраля 2019 г.

Контактная информация:

Хасинто Ривера де Росалес - д-р филос. наук, проф.; jrivera@fsof.uned.es 